\title{
RACISM WITH ANTIRACISTS: \\ Color-Conscious Racism AND THE \\ Unintentional Persistence of IneQuality
}

\author{
Matthew W. Hughey \\ University of Virginia
}

The latest turn in the sociological study of white racism argues that the paradigm of "color-blind racism" is the predominant form by which many whites unintentionally reproduce racist ideology due to ignorance, or dismissal, of structural racism. As a remedy, many scholars advocate that whites should turn to explicitly "antiracist" activism informed by structural analysis. Employing ethnographic data in a majority white antiracist organization as a touchstone for analysis, I problematize this arrangement by examining how racism is socially reproduced despite members' good intentions, knowledge of structural racism, and explicitly color-conscious ideology. Using in-depth interviews, fieldnotes, and content analysis of organizational publications, I find several mechanisms at work which, unlike the dominant "color-blind" approach, explains the persistence of an "antiracist racism."

“. . . effectiveness in anti-racist mobilization depends on the ability to make allies . . . anti-racism, despite what may be the intentions of its adherents — to oppose injustice and 'epistemic violence'—often concludes with it."

Howard Winant, 2001, p. 284

Matthew W. Hughey is a Ph.D. Candidate in Sociology and adjunct faculty in the departments of African-American Studies, Media Studies, and Sociology at the University of Virginia. His research, teaching, and publications have sought to synthesize the study of Race and Ethnicity with various strands of Critical Theory, Cultural Sociology, Media Studies, and Qualitative Methods. 
"A social and historical critique which does not consider the conflictual structure of its own discursive operations will only produce the constraints it is seeking to displace."

Samuel Weber, 1985, p. 111

White people born in the United States have inherited the social condition of living at the zenith of racialized pecking order. At the same time, it is also no longer feasible to assume the stability of a "normalized" whiteness whereby an invisibly privileged identity is safe and immune from political and/or cultural challenge. Today, there are vast varieties of whiteness. Such proclamations should neither translate as an acceptance of the reification of race into a hierarchical structural arrangement in which whites are beneficiaries of racism regardless of class, gender, sex, national origin, or stylistic concerns. Nor should such statements be taken as my licensure of unbridled cultural explanations by which race and white racial identity are more of a "process" than a stable "social fact."1 Rather, I am acknowledging that race-and especially whitenesshave reached a contemporary "crisis."

This crisis is underpinned by what Howard Winant calls "white racial dualism” (2004). Borrowing from Du Bois" notion of "double consciousness" (1903), Winant argues that whites have inherited "the legacy of white supremacy, from which they continue to benefit. But on the other hand, they are subject to the moral and political challenges posed to that inheritance” (2004: 5). That is, when whites enter into the arena of overt racialized political activism, they are often pulled in two disparate directions - toward an activism that is supposedly oscillating between two antithetical poles. On the one hand, there is the tradition of white racism: From hooddraped racists rallying around a burning cross, to the more wellgroomed, engaged, and professional white nationalists like David Duke who told his supporters: "We've got to get out of the cow pasture and into the hotel meeting rooms" (in Wade 1987: 368). On the other hand lays the activism of antiracist whites like Tim Wise, the activist-writer and director of A.W.A.R.E. (Alliance of White Anti Racists Everywhere), to the latest phenomenon of "diversitytraining" firms that operate with complicity inside the framework of modern corporate logic. Despite a commitment to the goals of 
white supremacy, nationalism, or separatism versus the goals of social justice, egalitarianism, and the recognition of the fundamental oneness of humanity, both phenomena are instances of attempts to resolve this crisis through the mainstreaming of a once radical white racial activism.

While the study of white racism has a long tradition in sociological analysis that has recently increased its publication tempo (Barkun 1994; Blee 2002; Burlein 2002; Ezekiel 1995; Ferber 1998; Langer 2003; Levitas 2002; Ridgeway 1990; Sharpe 2000), study of white antiracists remains relatively new and sparse. Many assume (scholars included) that white antiracist activism is a key solution to modern racism. Of possible consequence, many white, liberal, self-referential "antiracists" have received a "free-pass." As a remedy, this work examines antiracist activity, white identity, and the unintentional reproduction of racism.

The study of whiteness has attracted a great deal of attention from scholars across disciplinary boundaries. Although the impact of this intellectual movement has been less considerable among sociologists, there has nonetheless been a resurgence of interest in the sociological study of whites. Much of the research was originally focused on how whiteness worked as an invisible normative construct (Delgado and Stefancic 1997; Frankenberg 1993; Hyde 1995; Lipsitz 1998) whereby whites generally had a lower degree of self-awareness about race and their own racial identity than members of other racial groups (Brekhus 1998). Recently, work on whiteness has come to explore how whites minimize, acknowledge, and/or feel guilty about their privileged status (Doane and Bonilla-Silva 2003). Such a denial of racial privilege lies at the foundation of what scholars label “color-blind racism” (Bonilla Silva 2001, 2003). Color-blind racism's tenets assert that there is a fundamental equality of all racial groups, in terms of rights and experiences, and that social programs like affirmative action only further entrench racial divisions (Andersen 2001). This perspective reflects an understanding of whiteness that assumes its content is like that of any other racial group and that racism is now largely a thing of the past. Racism is then rationalized through an allegiance to abstract liberalism, naturalization, cultural racism and the minimization of racism. ${ }^{2}$ 
Such a stance does not hold up under scrutiny. There is increasing racial separation (re-segregation) in education and housing (Orfield and Yun 1999), whites are the most self-segregated racial group in the United States (Orfield and Lee 2006), and white hate groups have increased by 33 percent since 2000 (Potak 2005). As a remedy, one of the chief theoreticians of the "color-blind" school_Eduardo Bonilla-Silva (2001, 2003)—advocates transforming whiteness from an identity of social superiority to one of social responsibility. Such a transformation, he argues, would work as a counterbalance to color-blind racism, and would come in the form of antiracist whites that are attentive to the dynamics of institutional and structural racism. While such a critique, analytical model, and solution appear to carry purchase in the study of the "everyday whites" 3 in Bonilla-Silva's work, there are few theoretical models in place that can serve as an explanation for the reproduction of racism among antiracist whites when they are explicitly color-conscious and actively aware of the institutional and structural aspects of racism. This study aims to fill this gap.

Employing ten months of ethnographic data collected in an U.S. East-coast university chapter of a majority white international antiracist organization called "Reformed Relations" [henceforth RR] as a touchstone for analysis, I examine how racism is reproduced despite members' good intentions, knowledge of structural racism, and explicitly color-conscious ideology. In specific, through the use of in-depth interviews, fieldnotes, and content analysis of organizational publications, I find social mechanisms that, unlike the now dominant "color-blind" thesis, explain the persistence of racism in this setting. In what follows, I first examine the literature on whiteness and antiracism, paying special attention to how this study relates. Second, I introduce the reader to the data, methodology, and analytic frame employed in this study. Third, I illuminate the findings; and fourth and lastly, I present the conclusion.

\section{White Antiracism}

Over the past three decades, investigations into whiteness have emerged as a means to attend to lacking aspects within the socio- 
logical study of race and ethnicity. However, despite this recent interest, studies of whiteness are far from new. Scholars of color have long studied critical investigations of white identity in its lived expressions, as well as theoretical inquisitions into "whiteness" as an ontological concept. An explicit yet nascent interest in whiteness goes at least as far back as the work of William J. Wilson's essay “What Shall We Do With The White People?” in 1860. Such inquisitions into whiteness were continued by notable scholars and essays like Langston Hughes’ The Ways of White Folks (1934), Ralph Ellison's "What America Would Be Like Without Blacks” (1970), and W.E.B. Du Bois' classic essay "The Souls of White Folk" in Darkwater (1920). However, the "field" of whiteness studies is generally recognized as being introduced by Richard Dyer's essay "White” (1988) in the British film journal Screen.

Implicit in this research is the role that whites have in perpetuating or challenging racism. Out of the sociological views on whiteness and (anti)racism, four main paradigms have emerged: The first of these is an optimistic standpoint. Scholars such as Firebaugh and Davis (1988), Lipset (1996), Sheatsley (1966), and Sniderman and Carmines (1997) have concluded that anti-black prejudice is rapidly declining among whites, and that such indications reflect a changing cultural logic in society. These studies emphasize the profound legal and political advances in recent years. A second frame advocated by scholars such as Schuman, et al. (1997) demonstrates that racial perspectives are filled with a mixture of acceptance and intolerance. This is characterized by an approval of political liberalism and a growing rejection of policies like Affirmative Action (such as the recent Michigan state constitutional amendment that makes Affirmative Action illegal). Third, scholars like Bobo and Kluegel (1993), Dyer (1997), Lipsitz (1995), and Sidanius (2000) explicate that racial prejudice is still supported by a well-defined ideology of white supremacy. This framework argues that whiteness is basically a synonym for privilege and power regardless of context. And fourth, the new racism approach demonstrates that anti-black attitudes have blended with traditional Western value systems such as meritocracy and individualism to mask racism. 
The latter model aims to explain substantial variance as a new form of racism independent of older racial and political attitudes. Among the best-known efforts within this approach is "symbolic racism” (Kinder and Sears 1981, 1996; Sears and Kinder 1971; Sears 1988), "modern racism” (McConahay 1986), "ideological refinement” (Jackman and Muha 1984; Jackman 1994), "laissezfaire racism” (Bobo, et al. 1997) and most notably, "color-blind racism” (Bonilla-Silva 2001, 2003). All these perspectives emphasize that "new racism" involves a combination of racial and ostensibly nonracial attitudes. "Symbolic" racism is described as the combination of anti-black animus learned in childhood with a sense that black Americans are violating American values of individualism and self-reliance (Kinder and Sears 1981, Sears 1988). McConahay's (1986) "modern” racism is the combination of the beliefs that discrimination is in the past and that blacks are pushing too hard for equality. Jackman's (1994) “ideological refinement” emphasizes the discrepancy between high support of principles of equal treatment and low support for active government intervention to reduce racial inequality, with the discrepancy interpreted as indicating insincerity (Jackman and Muha 1984). Bobo, et al.'s (1997) "laissez-faire" racism incorporates belief in anti-black stereotypes, a tendency to blame blacks for black-white inequality, and resistance to active policies that might help reduce racial inequality.

The paradigm of color-blind racism justifies the continued second-class status of African Americans without actually sounding or appearing traditionally "racist." For example, many whites justify the continued second-class status of minorities as the product of market dynamics, naturally occurring phenomena, and/or blacks' supposed “cultural limitations.” These arguments mask anti-black racism and support fallacies that race no longer matters. One of the most influential scholars among this school of research is BonillaSilva, whose work Racism Without Racists: Color-Blind Racism and the Persistence of Racial Inequality in the United States (2003), has received critical attention. Bonilla-Silva empirically analyzes the various manifestations of color-blind racism with the goal of revealing the color-conscious result. 
Bonilla-Silva's cogent study reveals much about the dynamics of U.S. racism in the post "golden age" capitalist era. The solution, as Bonilla-Silva and many scholars suggest, is for these same whites to become educated about the institutional nature of racism and to then engage in “antiracist” work. Footnoting O’Brien's study of white antiracists (2001) as the brainchild for his solution, BonillaSilva writes, "I urge a personal and political movement away from claiming to be 'nonracist' to becoming 'antiracist.' Being an antiracist begins with understanding the institutional nature of racial matters and accepting that all actors in a racialized society are affected materially ... and ideologically by the racial structure" (2003: 15). However, only a modicum of research has examined the cultural logic, ideologies, mechanisms, and everyday lived experiences of antiracist whites to explore, simply, if such a solution is working.

While the "new racism" of color-blindness has been studied at length, and new scholarship is continually advanced, interrogations of supposedly antiracist whiteness are conspicuously sparse. There is minimal scholarship on white antiracism, and it is framed by a dichotomy of either celebration (Carvery and Bishop 1994; Frankenberg 1993; Katz 1978 [2003] O’Brien 2001; Thompson, Schaefer and Brod 2003) or critique (Bonnett 1993, 1997, 2000; Hughey 2006; Jensen 2005; Kivel 1996; Marty 1999; Srivastava 2005, 1996). Accordingly, the few studies that undergo a critical analysis of white antiracist activity focus mainly on how these groups unintentionally reproduce racism via various "color-blind” mechanisms. Such work would seem to support the dominance of the color-blind thesis as an explanation of the continued discrimination of non-white people in our contemporary moment. However, in this study, I find the explanation of color-blind racism untenable.

Using Bonilla-Silva's study as an analytic platform reflective of the lens of color-blind racism and the data from a white antiracist organization as the criterion for analysis, this study challenges two notable assumptions underlying the "color-blind racism" perspective. First, that whites reproduce racism fundamentally through a "color-blind" lens, when the whites in this study are explicitly color-conscious and hyper-aware of racism. Second, that the solution to "color-blind racism" is that whites must stop being 
"non-racist" and become "antiracists" who are aware of structural racism, when these antiracists whites (who have a thorough knowledge of the dynamics of structural racism) engage in a remarkable and unsettling reproduction of racist ideology in three specific valences: (1) beliefs in racial essentialism, (2) expectations of whites being the center and subject of racial discourse, and (3) contradictory viewpoints regarding racial segregation and the freedom of association.

\section{Data and Methodology}

\section{Data}

$\mathrm{RR}$ is an international antiracist organization founded in the mid 1990s. Shortly after the organization's genesis it was expanded to U.S. college and university campuses, where presently there are thirteen active chapters across the nation. On the university/collegiate level, RR's chapter memberships are divided into an executive board composed of the coordinators of the various discussion groups of 10-14 people per group that comprises the bulk of the membership activity in the organization. The same is true of the chapter studied at "Fieldview University." It is of special importance to denote that of Fieldview University RR chapter's twelve executive board members, ten (83\%) of them were white, one is black (8\%) and one is East Indian (8\%). ${ }^{4}$ Out of the eighty-five total members in this chapter of RR, only twelve members (14\%) are non-white. The discussion groups are purposely left small in size (ten to fourteen members) so to enable a substantial focus on discussion and personal experiences. My research was composed out of three data sources from within the organization: (1) Fieldwork in the "discussion group" level of the organization, (2) semistructured, in-depth interviews with various members of the organization in and outside of the discussion group, and (3) publications such as magazines, reports, flyers, and any textual information that were meant for public consumption. 
Methodology

Institutional Review Board (IRB) approval was sought and granted. In order to receive IRB approval, all identifying information regarding RR was changed and replaced with pseudonyms. Moreover, I offer no blatant or hidden clues as to the actual names and locations in order to protect the subjects and the ethnical soundness of the study. To study the unintentional reproduction of racism within RR, I triangulated (Gable 1994; Kaplan and Duchon 1988; Lee 1991; Miles and Huberman 1994; Mingers 2001; Ragin 1987) the data via: (1) ethnographic fieldwork in RR meetings, (2) semistructured in-depth interviews with members, and (3) content analysis of published material. Such a strategy was suggested by Knafl and Breitmayer (1989): “[M]ultiple data collection techniques contribute to the completeness function of triangulation by providing explanatory insights about data from varying sources” (234-235). This is similar to Jick's (1983) triangulation that enables the researcher to elicit data and suggest conclusions "to which other methods would be blind" (138). The general idea behind the "completeness function" is that triangulation in multiple methods leads to a "holistic" account where "gaps" are plugged by each successive method/data source. These three data sets gave me a more complete picture of these students' experiences than any single data set would allow.

The first valance of my study was participant observation in RR weekly meetings. Over 2005, I attended RR's almost weekly meetings. Specifically, RR met between January and May, while refraining from meeting during the summer (June through midAugust), whereby they resumed again until mid-December. Within this span, I attended twenty-eight meetings (90.3 percent) in total, missing only three. Meetings generally ran 90 to 120 minutes in length. Meetings were tape recorded and later transcribed and coded. My relationship with the group was that of a known participant researcher conducting a scholarly investigation. Thus, everyone in the organization knew my status as a researcher and consented to my presence at the meetings. 
To understand the cultural logic of this organization, I employed a constant comparative technique between theoretical questions and the simultaneous discovery of data. Through Smith's method (2005, 2002, 1987) of “Institutional Ethnography," via a modern and adjusted "grounded theory" (Glasner and Strauss 1967) approach, I paid special attention to how everyday experience is socially organized by means of the interweaving intersection of dominant ideas with patterns of local knowledge. The method combines inductive and deductive approaches in that it remained open to the discovery of data and theory. From the former, I understand that meaning is actively made. From the latter, I took a priori the assumption that social actors are embedded in a "ruling apparatus" or regime that coordinates their activity (G. Smith 1990).

The second aspect of this study is composed of semi-structured, in-depth interviews with members of the discussion group of which I was a direct part $(n=10$; black $=2$, white $=8),{ }^{5}$ as well as members from other discussion groups who agreed to my request to be interviewed ( $n=14$; 1 = black, 1 = East Indian, 12 = white). Each of the in-depth interviews $(n=24)$ was either audio recorded (transcribed later for analysis) or extensive notes were taken during the interview. Such interviews are used to provide a deeper understanding of the role that their ideologies and logics play in shaping their experiences as members in their organizations and how they extend those roles into their everyday lives. Extending Smith's (2005, 2002, 1987) approach to interviewing, I combined two modes of interviewing inquiry. The first is the common hermeneutic method, ensconced in ethnographic approaches, that aimed to understand how specific comments and situations countervail or complicate abstract generalizations. I examined how subjects make sense of various racial situations, which provided a glimpse of the forces that shape their organization and the criteria that reflect members' perceptions of the meanings of those social forces. The second approach to interviewing is what Han-Georg Gadamer characterizes as the "hermeneutics of suspicion" (1984 [2002]: 54) whereby I geared my questions toward revealing the meaningfulness of statements in an unexpected sense and "against the meaning of the author” (Gadamer 1984 [2002]: 58). I often accom- 
plished this by asking members to demonstrate what they meant by a certain statement, asking for clarifying examples, or more directly challenging the validity of a statement to observe how it would be defended.

The third and final aspect of the research comes from content analysis of publications. The publications selected for analysis were anything published for public consumption by RR from January 2005 through January 2006. Such material fell into the categories of recruitment, advertisements for events, and the dissemination of the organization's goals and purpose. In specific, I analyzed three newsletters; two "magazines" inclusive of poetry, artwork, political statements, and essays; fourteen flyers (mostly advertising for RR events), and four political statements/essays published in various Fieldview University campus newspapers. In order to analyze all relevant data, I employed content analysis to systemically identify the texts' meaningful properties (Brown and Yule 1983 [1989]; Fairclough 2003). To make valid inferences from the various texts, I felt that the classification procedure should be reliable and consistent. I adopted a research design comprised of the strength of quantitative approaches, whereby I examined textual content in a systematic manner, while I mitigated quantitative weakness in the creation of content categories to capture the meanings encoded in the texts. As a consequence, this method incorporated an interpretive approach in place of a purely empirical examination through four qualitative coding strategies: first, identification of the target audiences; second, classification of various formal features of the object; third, anticipated effects of the object; and fourth, ideological content.

\section{White Deconstruction and Non-white Essentialism}

Ethnographic inquiry often begins with extra-social scientific concerns (Lofland and Lofland 1995). I came to study RR through personal contacts and interest in the political agenda of the organization. If one is a student, administrator, faculty, or community member nearby Fieldview University, it is virtually impossible to remain unaware of RR. In many ways, these white antiracists are attempt- 
ing to express solidarity with social and political marginality. Yet, the ability to express one's own story, to live in accordance with a worldview that one has constructed based on a distinct moral code, is an act of self-determination that is decisively non-marginal.

To many of the members of RR, whiteness is conceived as an identity that is lacking "authenticity.” Yet, it can be reinvented based on a personal intention to rebuild that whiteness in a more inclusive, antiracist context. One white female RR member named Jane explained:

Everyone is not really down with what we do, or even the way we think about it. But you can tell the difference if you really look and pay attention. I mean, did you always really care about inequality? Or is it something that you picked up [said with a slight sneer in her mouth and irritated tone] and just did it because it's p.c. [politically correct]. People don't really mean it, you can tell who's authentic, errrr ... really means it; that they connect with people who are different.

Jane's comment established a connection between the differing forms of whiteness in relation to the trope of authenticity. I questioned how she could tell the difference, and she replied:

It's like a feeling of being real, like an attitude, not just something that you say. Like a general spirit in people that happens when they don't buy into the artificialness of the mainstream. You know those frat boys that talk about “diversity” but don't know anything about black people. It's all fake. It's like they just go and buy into the talk, they don't try to be less white, it’s kinda sad.

Jane makes it clear that whiteness is on par with a lack of authenticity. Additionally, she expresses that RR transgresses the border of talking about race in politically correct terms, into the land of living a life where one "knows . . . about black people." Here this austere worldview is configured as a moral signifier that evokes devotion toward inclusivity.

RR admits to rejecting a certain way of life and instead immerses itself in the professed aesthetic valuation of non-white cultures. This border-crossing is like an act of deterritorialization- $\mathrm{RR}$ 
envisions itself as nouveau desegregationists of white unauthenticated lifestyles. Many members engage in this attempt to access to "authenticity" by relating to the "cultural capital” (Bourdieu 1984) of non-white subjectivities. Michael, a white male member, stated,

When I first got to college I didn't have a lot of friends. I grew up Irish Catholic, and I started going to Mass, but I didn't really feel like people there were real. I almost felt repelled by the fakeness of it all. It was like this superficial nonsense about Ireland, not like clovers and drinking, but it was some huge game we all agreed to play and not talk about. It wasn't real. ... So I found out about [Reformed Relations] and thought this would be better. Three years later, here I am. I think I'm better off than at the church.

Mary Waters' landmark work Ethnic Options (1990) rigorously demonstrates the changing nature of ethnic whiteness in the U.S. among a sample of suburban Roman Catholics. Her research validates Herbert Gans' (1979) suggestion that "symbolic identification" with racial and ethnic identity is akin to a leisure-time activity for many whites. Finding that ethnic homogeneity varied directly with age, Waters' work disputed prevalent sociological theory that saw ethnicity as fluid, but not as changing within the lives of particular individuals. While Waters' population believed in a biological nature of whiteness, many of the subjects in this study believed in the social construction of whiteness and sought to recreate their racial identity as being ontologically antiracist. They want their ideology to constitute their identity.

Allie, a white female member stated, "I feel that if people simply try, and just decide to make an individual effort to get outside of their whiteness then they could make a lot of change and do a lot of good.” I asked Allie to clarify and she replied, "I don’t know. Just start getting in touch with non-whites and learning." This non-white authenticity and desire to "get outside of their whiteness" attracts the members of RR as a method of white deconstruction that appears trendy, cool, and cutting-edge. Natalie (white female) stated,

Being here [RR meetings] every couple of weeks often makes me feel less white, less of an oppressor, less of a bad person. I get 
the whole white privilege thing, and it's so true. I know that my consciousness is being raised. I know this might sound weird, but, I mean you understand, because ... well, its like I'm a part . .. I mean I know I'm not because I couldn't, but yeah it is, it is like I'm a part of the Indian community when I go with Rita [East Indian female] or like I'm a part of the black community when I go to a party with Lisa [black female] I know it's not total, but it's like I'm slowly recreating myself.

I asked Natalie if she thought others saw her in the same way that she viewed herself; as more of a member of an "othered" non-white community. She replied, "Oh, I'm not sure, I think those who know me on an individual level would say 'yes.' But most people don't care about those things, they aren't concerned with what's important.” Along these lines Michael stated,

I don't see other people going out of their way to be with other races. When I see you guys [referencing Kris and Lisa, the two black members in attendance at the meeting], I smile, because I know I'm crossing a boundary [my emphasis] that others are not. You guys make me feel incredible, that's why we do this, ya know? People can learn, uh, you know we have to fight this wall in between us, no one else is gonna do it.

The members feel they are somehow shedding the garbs of normalcy which they think are inherent to whiteness through nonwhite (especially black) interaction. RR members frequently define themselves in terms of their whiteness but also proudly contest that existence. Thus, by adopting a worldview in opposition to a mainstream white environment, members try to articulate autonomy from the racial status quo. In shunning the gains of whiteness and trying to act as a part-time "other," white RR member are attempting to live in a state of critique-making critique not just an attitude, but also an ontological supposition. Ginsberg writes, “... the decision to 'pass' as [an "other"], to self-construct an identity perceived by a white majority as less desirable, disrupts the assumptions of superiority that buttress white privilege and self-esteem” (1996: 15).

Ironically, even though RR is shifting toward an outwardly perceivable social constructivist stance, they end up essentializing both 
whiteness and "otherness" by situating mainstream whiteness as some "fake" norm against which the "authenticity" of non-whiteness is compared. As David Roediger states, “. . . the consciousness of whiteness also contains elements of a critique of that consciousness and that we should encourage the growth of a politics based on hopeful signs of a popular giving up on whiteness . . by exposing, demystifying, and demeaning particular ideology" (1994: $3,12)$. Therefore, RR's method out of this ontological trap of whiteness appears in the form of the rejection of cultural aspects associated with white normalcy, coupled with the emulation of the lifestyle of marginalized subjects. As Michelle (a white female member) stated to me in a personal interview,

Growing up in my all white town, I was bored, you know? I mean, you get it right? [Get what?] [Michele laughs:] Come on, we both saw through the b.s. The capitalist, dominant ideology game. Whiteness is all a part of that, being normal. But I've thought about this a lot you know, and I think its killing us. Being white... so I don't even try. [So, what can we do?] I try to live as an example, to learn about and enact the experiences of people of color.

Michelle's account shows both an amazing amount of consciousness and reflexivity in her self-image, as well as a disturbing contradiction of primordial naturalness and essentialism that she is re-inscribing on the margins. While one should not discount the underlying political impetus of this emerging culture of antiracist resistance, one should also critically investigate the mechanism by which socially conscious antiracist whites make sense of their social positioning. Rather then being an "other," many of the white members of RR make a conscious decision to experience a different sense of the world by associating with the antiracist organization and a small number of people-of-color.

As members recounted how their border crossing was personally important to them, they also were adamant that the acts of re-articulating their whiteness against the grain of a "normal" and "racist” whiteness were also acts of fighting structural and institutional racism. During an RR meeting, I observed the following discussion between three white members: 
[Kim]: It seems that the real danger out there today is institutional racism ... you know, profiling and stereotyped caricatures of blacks and Hispanics in the media.

[Mark]: Yeah ... I think we need to find some shows to watch over the next few weeks during our meetings, and then we can discuss them, that are good examples of shows that don't fall into the category of institutional racism, but that show the real life ... or the, ummm, reality of being black or Hispanic, or Asian. I mean, not something that is mediated through a white lens, you know?

[Michelle]: Like what?

[Kim]: I think it needs to have a critique of white supremacy, not in the formal sense, but in the sense that we as white people are the oppressors, but are just as trapped in the system of oppression themselves.

[Mark]: So if we can find instances of films that demonstrate how to be less of an oppressor, less white, less fake and inauthentic, we can fight this ...

[Michelle, abruptly interrupting Mark]: It’s not that simple though ... this is something deeply entrenched in who we are as people. . .

I later followed up this discourse with Jasmine (a white female member) in a personal interview. Jasmine stated, "We do our best to deconstruct negative black images. For instance, the media is full of negative displays of black men. In RR we provide a setting for black members to 'set the record straight . ..'” she said, putting up both hands and using her index and middle fingers to denote "air quotes.” She continued, “. . . as well as for white members to learn how to learn about the real black experience. Since institutional racism is so insidious, we combat it. It's great to know that every week I am slowly combating racist messages. I feel like I'm actually doing something worthwhile.” While Jasmine acknowledges that racist messages are common, especially in the media, she neither sees how RR recasts black members as subjectivities responsible for teaching whites how to "properly" engage in discourse that is "antiracist," nor how blacks are seen as reflective of an authentic antiracist, real, and progressive identity. As cultural sociologist Bethany Bryson writes, "Cultural tolerance should not be conceptualized as an indiscriminate tendency to be non-exclu- 
sive, but as a reordering of group boundaries” (1996: 895). Such a deconstruction of traditionally racist messages does not destroy racial boundaries, but rather transforms and reestablishes them. These troubling and complex aspects of racial politics continue in $\mathrm{RR}$ with respect to representations of blackness: from the romanticization of the impoverished black gangsters and neo-nationalism in contemporary rap music, to the celebrations of the Cosby-esque black middle and upper class, the contemporary images of blackness are relied upon to challenge hegemonic constructions of whiteness. This occurs even as RR rewrites and reproduces forms of patriarchal authority, enveloping some of its most disturbing aspects of racism in certain black vernacular style and expressive performance.

Within RR, blackness is an "imagined community" (Anderson 1983) that is the basis for rearticulating whiteness as antiracist: as a kind of counter-cultural hero worship in the case of rappers; as naturalized and commodified bodies in the case of athletes; as symbols of menace and threat to the established order in the case of black gang members; and as noble warriors for "the cause" in the case of Afrocentric nationalists. While these varied images travel across different fields of media representation and social discourse, RR essentializes all these forms into a concept of all that whiteness is supposedly lacking. Thus, RR's use of essentialized blackness in these cases stands for the black nation, the black family, and the authentic black self. In light of insights by post-colonial theory, the persistence and strength of such monolithic, fixed, and "authentic" contemporary conceptions of blackness among white antiracists should give us pause to ponder the rather uneven effects of such interventions into whiteness at the level of theory and lived experience. The transgressive critique of whiteness is the catalyst for its stabilization.

\section{Interpellation of the White Antiracist Subject}

While the RR members often attempted to deconstruct racist ideologies and common stereotypical misunderstandings between racial groups, there was a surprising emotional response emitted by 
many white members when encountering a non-white (especially black) cultural product, tradition, and/or cultural folkway that did not fit within preconceived notions. That is, I found that whites in RR expressed substantial negative emotions, ranging from slight disgust to overt hostility, when they felt excluded or marginalized from understanding the dynamics, purpose, and/or nature of something thought to be "black" (e.g.: a rap lyric, "hip-hop" clothing style, an aspect of black history, or the nature and work of a black organization).

I argue that this observed negative dissonance is best understood not as a psychological state, or as an entirely internal process, but rather through the concept of "interpellation" (Althusser 1971: 171-183). Interpellation is a concept that describes the process by which an ideology addresses an individual subject and effectively produces him or her as an effect. In other words, the social situation always precedes the subject (in this case the individual RR member or RR as a collective organization). Interpellation specifically involves the moment and process of recognition of interaction with the ideology at hand. Althusser writes, “. . . ideology 'acts' or 'functions' in such a way that it 'recruits' subjects among the individuals (it recruits them all) by that very precise operation which I have called interpellation [italics in original] or hailing” (1971: 174). As related to the social dynamics of RR, I found that white RR members were offended by various cultural forms thought to be "black," due not to the content of the raced cultural form in question, but due rather to whether they felt it was directly related to their everyday experiences and worldviews.

For instance, at the conclusion of one RR meeting, members were given an assignment for the next week's meeting. They were asked to bring examples of "things from black popular culture" that they felt were commonly used by "the mainstream" as an excuse to label black people as stupid, deviant, dangerous, and/or inferior. The exercise was intended to provoke a discussion about the breadth and insidious nature of institutional racism against black people that is operationalized through everyday aspects of popular culture. The coordinators of the meeting hoped that by discussing how baggy jeans (for example) had become associated with younger, 
uneducated, black males, it would open up a discussion to realize many of the cultural contradictions concerning institutional racism in society-namely that black cultural forms are often seen as dangerous or deviant and are being banned by high school dress codes across the country, but when the white lower class dresses in a similar fashion, such is often overlooked.

This rather clever exercise illuminated some of the ideological dynamics of RR. As the next meeting approached, I wondered what examples of "black popular culture" members would bring as examples of institutional racism. As the meeting began, people were excited to talk about their "homework" and the meeting took on the atmosphere of elementary school "show and tell." I was astonished at how critical many of the members' comments were and how in line with current sociological thought regarding racism many of the assertions proved to be. In fact, some of the examples, which I thought would be contested or argued with as an example of prejudice or discrimination, were accepted with complete faith as jumping off points for the discussion of institutionalized racism. For instance, one member brought a collection of rap songs that had explicitly anti-white lyrics, one of which was a song (1993) performed by a rapper named Apache: "Kill the white people; we gonna make them hurt; kill the white people; but buy my record first; ha, ha, ha." ${ }^{\prime 6}$ Instead of critiquing the text immediately as a reflection of anti-white ideology, the white members of RR talked about the complexity of such a lyric that was produced by a black artist working under a white record label; as a lyric that is a reflection of the pain, suffering, and frustration with white inaction or apathy against racism and poverty; and how such lyrics are often used by politicians as cannon-fodder for pushing conservative morality agendas through legislative branches of government.

Later on in the same meeting, one of the only black members [Kris] was explaining to the group that his fellow students and his professors often treat him differently when he grows his hair into an "Afro." While discussing his feelings regarding discrimination based on his explicitly "raced" haircut, he began to speak about how his comb or "Afro pick" (that has a black fist at the end of the handle) when combined with his Afro hairstyle, often seemed to 
scare or disturb white people, especially when he wore the comb in his hair. Allie, leaning over in her chair so far that she almost fell out, immediately started to question Kris about the comb. She interrupted Kris mid-sentence,

[Allie:] So wait! You mean that your comb has something to do with Black Power or something like that? [Kris:] Well, I mean ... yeah it used to, back in the day with the Panthers and stuff, but I guess now it's just sort of trendy. It's something to have that ...

[Allie:] Panthers! Those were the guys with the black leather jackets and ... I mean, yeah I could see how it might scare some people.

[Kris, laughing a little uncomfortably:] Yeah, but it’s more like a fashion thing, you know? It still has some meaning with race, I mean, yeah, it's got a black fist on the end of it and all. I guess I would think it was strange if I saw a white person using one, even if they could...so yeah, it's still about Black Power I guess. [Allie:] Cool, I didn’t think I would get to learn about Black Power tonight.

As I looked around the room, many of the white members were vigorously scribbling down notes (note taking by members is a common practice in RR, which also enabled my note taking as a researcher as a less intrusive presence) in a hurried fashion so as not to miss out on the chance to "understand" Black Power. By equating the comb with an already reductively established notion of Black Power, white members were able to digest a movement that they did not see as directly relating to their identity as white people. In that instance, the political movement of Black Power became a specter whose hagiography was encoded in a simple, small comb. The mood in the room was one of excitement and elation: white people were "learning" about Black Power. From there, discussion turned to how stupid people are when they are scared of a comb. However, after about a minute of silence Kris spoke again:

I know you think that the comb is about Black Power, but there's more to it. I mean, I guess a comb really has nothing to do 
with Black Power ... its not like we were asking for equality in relation to combs! [Kris said with a laugh, which everyone else joined in on]: I mean ... [long pause] . . . Black Power was about a demand for justice and power, there is a lot more to it, in large extent it was a middle finger to the Establishment. [Kris said as he emphasized the word "Establishment"] [Allie]: So what can we learn from it now? I mean, what good is it today. . . . I mean . . . uh . . . those days are over right? It's not really a productive thing, as I thought Black Power had to do with kicking white people out of civil rights organizations ${ }^{7}$... I mean what good is that? I just don't see my role or place in it. I think the best thing about it is the spirit and symbolism that it now evokes . . . if you think about it, it's kind of good that a comb can scare some white people, maybe it's good for them. It's good to make people feel uncomfortable.

It is telling that the import of the Black Power movement was reduced to its symbolic power encoded in a Black fist comb. Here, if the ideology of Black Power did not interpolate white people within RR as "always, already" good antiracists, then the ideology was not needed, or only useful in interpolating other white people (assumingly non-antiracist whites) in order to scare them or make them feel uncomfortable. Not understanding and lacking control concerning the event/idea/product in question became more important than the event/idea/product.

A further indication of this dynamic occurred at another meeting directly involving myself as a researcher. One evening at a RR meeting, the group was discussing an upcoming black fraternity and sorority step-show, an event often widely attended by interracial audiences at Fieldview University. I was asked if I had knowledge of Black Greek step-shows and the tradition of "stepping.” I replied that I was in fact a member of a Black Greek fraternity ${ }^{8}$ and participated in competitive step-shows during my undergraduate years.

After disclosing this information, the white RR members were incredibly excited: I was immediately seen as an example of what white antiracism could accomplish - as I am a white male who was allowed membership into the rather closed and secret brotherhood of a Black Greek fraternity. Suddenly Michael asked if I 
would teach everyone some of my fraternal steps, and everyone else started cheering me on to do so. However, I politely refused citing the rationale that Black Greeks are extremely particular about teaching steps to non-members, because there is a feeling of possession over those steps as they carry symbolic meanings that are representative of fraternal ideals and traditions. RR members' response to my refusal was shocking. I was rebuked for being "inappropriate" and chided for not engaging in what was being considered my "duty" to teach them as I was allowed to attend RR meetings.

Jane stated, “I can’t believe you won’t teach us . . . it's just stepping . . . that's kinda inappropriate don't you think? I mean, we're trying to learn more about different cultures...it's like a duty to teach others about things they don't know." In an attempt to defuse the situation, I responded that I would be more than happy to teach them whatever I knew about stepping, but not the act itself. I explained that if they learned specific fraternal steps, such an action could be perceived as a flagrant act of disrespect or even theft among my fraternity brothers and resultantly, would be counterproductive to the goals of their organization. To this Natalie replied, "See, that's part of the point, I know you are here to research race and whatever, but we can teach you some things too. You're being exclusionary [my emphasis] . . . what's the harm in us just learning, especially if it's like learning a new dance step or whatever?”

This example points to an important facet of their cultural logic. To RR, knowledge that is exclusive to non-white racial groups, whether grounded in specifics like the traditions of "stepping," or larger epistemological worldviews, is framed as self-segregating and exclusionary. Many white members simply feel entitled. Sharing raced knowledge is seen as breaking down walls of exclusion. However, it is explicitly a one-way street. Rarely are the traditions, cultural practices, or common worldviews of what makes up "whiteness," uncovered or even discussed unless it is in relation to what whiteness lacks. Rather, "positive” interracial contact takes the form of non-whites teaching their traditions to whites so that it is internalized to the point of comfort. The members of RR seem 
unaware of the reductive and symbolically violent aspects of this relatively narrow method of interracial and intercultural contact.

This dynamic is not simply a psychological one as it is inextricably intertwined with the "ongoing accomplishment" (Garfinkel 1967) and interpellation of white identity. White RR members expect to be hailed (interpellated) by whatever black cultural form, idea, tradition, etc. they encounter, and thus desire unmediated knowledge of and access to it. Their identity depends on such access. When black culture, or more appropriately, culture coded as "black" functions in explicit and distinctive ways that exclude or marginalize white people, which does not have to be about antiracist politics in distinct terms (e.g.: Black Power), it alienates a good percentage of white people by definition, or rather the lack of the expected interpellation of a white subject centered in the debate alienates white people. Because there is more often than not a white neo-colonial attitude toward blackness, black refusals to interface with whiteness often come across and feel like aggressive and exclusive forms of alienation. When white members in RR did not understand the political import of Black Power or the symbolic importance of black control over the act of "stepping," they took it as a direct offense that there could be a black cultural form that excludes their participation or a cultural product to which they could not be privy. They were offended simply, because they assumed their identity, or ontological presence, is a guarantee to be hailed as an all-knowing racial subject with unlimited access.

\section{De/Re-Segregation}

As discussed prior, the members of RR enact culturally tolerant actions that appear transgressive, progressive, and antiracist. In an attempt to engage in structural analysis, the members tend, rather habitually, to mould their analytic categories according to colonizer/colonized, segregation/integration dichotomies. This is not at all to imply that the analytic and empirical weight of this dichotomy should be downplayed; rather, these binary axes stand in need of being re-considered. Failing this, one might conclude that $\mathrm{RR}$ is a universally tolerant and absolutely racially inclusive organi- 
zation. As both Allie and Lisa (white and black members, respectively) stated,

[Allie:] I know what we do and how we get our goals accomplished ... it's apparent that we don't self-segregate like others do. It's amazing to think about how similar some organizations are to how it was in the forties or fifties, you know, before the Civil Rights movement.

[Lisa:] No kidding, who in their right mind wants to look like, or even think like, they do? We practice what we preach; we're way more inclusive then other organizations [my emphasis], we're not going to be responsible for going back in time.

Akin to these statements, Jane stated,

I don't want to say that I get a kick or a rise out of coming to [RR], I mean I enjoy the company and I have made some real friends with people of color. It's a safe place from, like, other people who ... who just want to cause problems. I mean ... look ... I don't mean for this to come off as bad, but a lot of black people or minorities are pretty mad, and it's understandable, but that anger has some bad consequences too, no one wants to listen to you screaming at them telling them they're racist. I hate that, and I know a lot of others do too. Instead, we need to move away from such personalized rants and engage in structural analysis.

As emphasized by Allie, Lisa, and Jane, the dichotomy of the segregation/integration model not only accentuates RR's critique of structural racism, but also frames non-white "others” as more than the victims of discrimination, but as the partial cause of racism through “self-segregation.” RR members, using a lens of post-civil rights multiculturalism, view racial separation as clearly immoral. During an interview with Allie, she stated,

People have worked so hard to break down these barriers, these immoral laws. And here we are, going right back to it. I refuse to be a part of that. I read that book you know? ... about white kids in the cafeteria ${ }^{9}$ and it's so true, I mean, we all self-segregate and that's wrong. [Author]: Why do you think we do that? [Allie]: I guess because it's a leftover from the past, ... and going back to 
that freely is almost as bad as not being allowed to be together.

It's just sick and makes me upset.

Allie's staunch views are not atypical. Indeed, something must be said about the decision of so many white students to join an organization dedicated to antiracism. Allie's passionate disgust for segregation is admirable in considering its implications for a democratic future. However, Allie's choice in RR as a majority white antiracist organization, actually segregates herself more than if she was not in that organization ${ }^{10}$ or if she had joined one of the many other antiracist organizations on Fieldview's campus that are mostly demographically dominated by people of color. ${ }^{11}$ Her distaste for segregation appears to be one-sided-a decisively myopic view that holds people of color responsible for their decision to be in racially homogenous situations, but not for whites when in the same situation.

Within this logic of self-segregation, non-white "others," especially African Americans, are reduced to being a part of the racial problem at Fieldview. For example, Charles (one of the few black male members of RR) stated,

I mean, we don't have a lot of black people in the organization. Actually, we are especially low in black members. And we don't have any especially "strong” black people in the heart of the community, you know? [Author]: What do you mean by "strong"? [Charles]: Well, due to my experience of not being poor and because I don't dress like most of the black folks here, I'm on the periphery of the black community. I mean, I am black, but I don't have a voice there, so I don't even try. It's like they [African Americans] self-segregate. I don't really see what they are trying to do; it's pointless! What can they do? ... so I don't even try to get involved with them. That's why I'm here [in RR], to do what I can.

Charles' statement provides illumination of how RR's approach seems unique and beyond reproach. RR's views itself as the premier antiracist organization on campus. In an RR meeting Jane stated, “Our process, our vision . . . is different. We don't try to appease or make people feel particularly great about race. But we 
do try to get people to open up, to examine what is really on their minds. I don’t know any other group with that purpose.” Comments like Jane's are indicative of the cultural logic of uniqueness that underpins RR. Their dialogical sense of self depends on a view of other organizations as "less-than.” As Natalie stated,

We are often called upon by the [campus] administration to conduct activities for the larger campus. Every year for orientation we conduct a skit that orients freshman to the campus and the stupid racial cliques. This one time we poked fun of [sic] this one bus stop where all the black kids always congregate, I mean isn't that silly? We don't have segregation anymore, they don't have to do that! Shouldn't we all be waiting for the bus wherever we want to?...I don't see campus officials asking other groups to do what we do, it must mean we are doing something right... and even if we aren't, we are at least reaching lots of people and opening up opportunities for dialogue. ${ }^{12}$

Natalie's logic is indicative of how RR frames minority student collectives, whether official (organizations) or unofficial (a de facto minority student meeting spot i.e., a bus stop) as "self-segregation.” By framing minority, especially black dominated organizations, as the problem, instead of as an alternative solution to racism, RR shifts the focus on the genesis of racial problems to that of other Fieldview students.

Black organizations, as framed by the RR's public discourse that is legitimated by campus administration, are reduced to fringe, radical, and illogical organizations. Allie stated, “I don't see other organizations really doing anything. I mean, they [Historically Black Greek-Lettered Organizations] have their step-shows and parties, but do they really try to solve problems? It actually seems they only perpetuate racial divisions.” Allie's comments show how RR membership is, in general, unaware of the social service and activist activities of other organizations, especially black-dominated ones. Another member named Michael stated,

We try to work with lots of organizations, the ones usually willing to work with us - that has usually been groups like the Chris- 
tian Student Union, Hillel, and the international students. Other groups, especially the black groups, well ... we haven't worked with or co-sponsored anything with them. I guess they're too busy to work on the important [my emphasis] stuff.

The plethora of non-white organizations at Fieldview University that hold frequent meetings and public activities designed to both educate fellow students and the outside community in order to alleviate racial conflict are systematically ignored by, or not known to, RR.

The frequent use of inclusionary tropes in RR's private and public discourse (one recruitment flyer stated: "Think Self-Segregation is Strange? Join Reformed Relations and Change Culture") becomes a powerful symbolic form. This symbolic inclusion for changing culture has an implicit social theory behind it. It assumes that culture directs human actions by way of psychological ideas and values and that life is composed of those ideas.

As Bethany Bryson wrote of mainstream antiracist and multicultural logic:

If we could improve the way they think, people would behave better and we would have a better, kinder, gentler society. Step 1: Change culture. Step 2: Relax - the rest will fall into place. That's the popular version of the multicultural plan, and the people who were putting the idea to work ... were pretty excited about it. ... If this theory of omnipotent culture is correct, tinkering with culture could, indeed, be an easy way to change the world. But it could also be extremely dangerous ... (2005: 7).

RR does not destroy racial boundaries, but rather transforms and reestablishes them within their inclusive discursive frames.

RR meetings are viewed as safe-havens, places to come together and discuss feelings regarding race and racism, out of which the group members intend to fight racial inequality. However, there is a complex system of boundaries at work that labors to use both white and non-white subjectivities to rationalize some actions and discourses as more or less appropriate. Natalie stated at a regular meeting, 
It's great that we can come together like this. Honestly, sometimes I just don't feel like coming some weeks. But I make myself come because....uh, it might sound weird, but I feel like I'm better than my roommates when I get home. I mean, they may have gone out and done something more fun I guess [awkward laughter around the room], but I know I get to be around people and say things that they would never do. We all know how some people can be, and some people just won't hang out with others if they are different.

Natalie's comment shows both the moral pedestal and the beginning inklings of a process of "othering" that occurs through the presence of the few black members in RR. When Natalie stated "we all know how some people are," she was delineating a moral boundary judgment on other white people (using the reference of her three roommates, whom I later discovered were all white). She viewed her roommates as being in possession of overt prejudicial attitudes and worldviews that were morally "less-than" her own. Additionally, Natalie was referring to the couple of non-whites ("I get to be around people") who are a part of RR in order to defend her moral positioning; using them as a social buffer whose very presence elevates her position based on actions that are read as liberal and tolerant.

This logic is not aberrant. One of the co-chairs of RR stated during an open recruitment meeting, "The point is to be changed, to be changed by people different than you. This kind of talk will make you change the way you see the world.” Accordingly, race and gender scholar bell hooks writes of this logic of inter-racial contact, “. . . frank expression of longing, the open declaration of desire, the need to be intimate with dark Others. The point is to be changed by this convergence of pleasure and Otherness" (1992: 24). The change of which hooks speaks is a critique of the fetish of marginalized "others" by the white center. To RR, the change should come about through racial boundary transgression. To RR, the comfort of "tokenized" blackness carries a very real meaning because it is a modern day form of social desegregation, whereby raced social networks are seen as the major racial hurdles. Jane stated, 
It's great being here [RR]. I feel so knowledgeable when I leave, like when you do something good for someone else just because you can or want to. It's like, kinda corny, I know, ummm, but ummm ... I just feel better, and everything's ok. I mean, I know everything's not ok really, but I feel better about things.

The small membership of non-whites fulfills the role of a feelgood balm for white racial sensitivities. RR fits well within popular culture's ideological conceptions of political multiculturalism. For $\mathrm{RR}$, the simple presence of people-of-color amongst whites appears to be a victory in the racial "culture wars." Likewise, the few black RR members "buy into" this social hierarchy in order to gain in-group status and relative influence among members. Again hooks writes, “. . . marginalized groups, deemed Other, who have been ignored, rendered invisible, can be seduced by the emphasis on Otherness, by its commodification, because it offers the promise of recognition and reconciliation" (1992: 25). The few black members often find themselves "spokespersons for the race" as they are forced into the roles of black teachers for white pupils in the study of a reductionist, vulgarized form of blackness. Upon conducting a one-on-one in-depth interview with Kris, a black male member of RR, he reluctantly admitted that he sometimes felt "used" by the organization. Kris stated,

... it's like, I get so tired sometimes. It can be so repetative, [I] don't know why I do it. [“Do what?”] Oh, go back every week. It's like, whats the point? It seems like I have to explain everything three or four times, like I'm a teacher [my emphasis], and I guess that's fine, I shouldn't complain, we don't all come from the same place. But sometimes, I just want to scream. And then I get grief from my other friends, like, 'Why do you go to those stupid meetings?' . . . feels like I'm being torn [my emphasis], like I'm used on one end and ... I don't know ... like my own folks [fellow black students] don't appreciate what I do.

Kris' views are representative of how the dramaturgical role of black membership is kept in check by the governing white liberal logic of RR. When black members diverge from this "teaching” role, they are often perceived as ungrateful, angry, and unproductive. 


\section{Conclusion}

The purpose of this work is neither to demonize whites for the reproduction of racism nor to make a qualitative judgment about white antiracism. This article is to accentuate my initial point: that antiracist work among whites even with the knowledge of institutional racism and in viewing the world in color-conscious ways, still allows for - and maybe even facilitates - the reproduction of racism. While the effects of color-blind racism (Bonilla-Silva 2001, 2003) are real and devastating, we must not uncritically accept the "solution" of simply engaging in structural analysis through an "antiracist" politic. We must consider a metacritical framework whereby the ethics of the intersections of antiracism and constructions of whiteness is put under the hermeneutic spotlight. This is all the more essential when the white antiracist movement shows all the signs of continuing to grow exponentially, not least after substantial growth in the corporate diversity sector, the "new abolitionist" strain of academic white antiracist thought, and the widespread reach of white antiracist internet sites.

It should be mentioned that the politics of white antiracism as a discursive and ideological framework for legitimating racial discourse represents a favorable force for change. Yet, white antiracist work often slips into a myopic narrative of inclusion represented by multiculturalism as yet another increment in the institutionalization of 'good' (legitimate) difference and 'bad' (threatening) difference. It is against this backdrop that the troubling channels of influence traversed by multiculturalism intersect with white antiracism. To suggest as much is to invite renewed consideration of how white antiracism does not, contrary to popular belief, often challenge racism.

To paraphrase the epigraph to this article, we must avoid reiterating the critical configurations that we are attempting to repudiate. Herein lies the corrosive rub: how do we (re)write the terms of a critical white antiracism that avoids merely repackaging difference within the neo-liberal, and invariably empty, wrapping of multicultural inclusivity? If we inquire into the nature of the discursive institutions that white antiracism instigates, then we must simi- 
larly inquire into how white antiracism, in an attempt to answer to multicultural priorities, effects a similar institutionalization of difference. Racism that is activated in the form non-white "others" as spectacles who only have voice when interpellating the white subject, or when serving as entertaining exoticism while teaching whites about things previously unknown, should be a startling wakeup call for the tenacity of racism even among those who are dedicating their lives to antiracism and the understanding of structural racism.

This problem is squared, so to speak, if we address the fact that the dilemma here continues to rotate around non-white otherness and who gets to speak for, categorize, and interpret, that otherness. For Linda Martin Alcoff (1991-92), the problem of speaking for others generates a further misleading emphasis on the notion of authentication to the extent that "persons from dominant groups who speak for others are often treated as authenticating presences that confer legitimacy and credibility on the demands of subjugated speakers" (Alcoff: 9). The politicization, or situating, of non-white others, while preferable to its depoliticization (and hence homogenization through dehistoricization), is nonetheless not without its own distinctive pitfalls.

By being mindful of contact resulting in possible cultural cooptation and exploitation, the question of raising an antiracist consciousness among white and non-white alike would be cultivated with an orientation rooted in both a structural analysis and an inquisition into the cultural contradictions of whiteness. Borrowing from Fanon, white critique would "grasp its narcissism with both hands" (1952) and begin to resolve its contradictions by examining how whiteness both wields power and is constituted by it. An effectual and potent white antiracist politic can operate within several registers:

(1) It must focus less on the conceptual make-up of what whiteness essentially is. One of the largest problems with the white antiracist praxis I encountered was their reification of racial identity. Despite warnings against using whiteness as a monolithic concept in much of the literature these white antiracists read, most of the discussion reveals, an essentialist tendency. This becomes more 
problematic when deeper theoretical and practical problems are raised. Despite the explicit adherence to a "social construction" approach to race, these white activists seem to employ it simply to argue against biological conceptions of race. While this is fine and well, they fail to consider the cultural complexities and historical rootedness of social construction that makes for the existence of whitenesses, not simply whiteness.

(2) Conversely, activists may try to make whiteness everything. For instance, Michael Eric Dyson writes that whiteness is an "identity, ideology, and institution" (in Chennault 1998: 300). If it is all these things it becomes analytically useless. As Clark and O'Donnell write of whiteness: "[T] reference it reifies it, to reframe from referencing it obscures the persistent, pervasive, and seemingly permanent reality of racism” (1999: 2). A solution is to specify the "field," to borrow from Bourdieu (1984), in which the power and meaning of whiteness operates (Hartigan, Jr. 1999).

(3) White activists, while talking explicitly about race and situating their activism in analyses of privilege, hardly mention postKeynesian capitalism, split labor markets, xenophobic nationalism, immigration reform, school tracking, fundamentalist religiosity, and the raced character to health disparities, to name just a few. Instead the focus is often on the "norm" that whiteness creates. In the end, such white activism tells us little about the processes of racial subordination, and instead focuses on the subject of white identity. Like studying diversity without oppression, there is little analysis of the lived experiences of white supremacy.

(4) Piggybacking off the last point regarding power, white antiracists are starting to find inspiration in the academic subfield of "whiteness studies" that has gained a critical purchase in studying the mechanisms of the construction of white identity from an "objective" and "scientific" point of view. To promote the study of white culture without an attending discussion of power and oppression in real life terms is to play a dangerous game in which the project can easily be co-opted to defend white identity or to advance explanatory models whereby discussion of whiteness end up marginalizing the needed attention on non-whites and their position amidst a social arrangement of inequality. 
(5) Another danger with the rising tide of mainstream white antiracism is that it is leading to the proliferation of "racial sensitivity" workshops and "diversity training" instead of political struggle. Antiracist seminars that are structured to inform whites of their "inherent racist nature," and then told to go out and raise the consciousness of other whites, are not productive strategies. Such a plan might be well intentioned (akin to a twelve step program where the first step is "admitting" and the twelfth step is engineered toward the functionalist re-entry of the "healthy" subject back into the status quo), but we can neither allow ourselves the luxury of thinking such an activity is a progressive social movement nor that such activity is about political or spiritual struggle. Such an endeavor often helps white people feel good about their own subjectivity - like a form of religiously-inspired "white confessionalism" whereby guilt is absolved through the penitence of saying fifty "Bad Whiteys" - but it does nothing to effect structural-cultural change. While there is some truth that activists should seek out a collective in which they feel good about who they are, such a dynamic has shown to distract from the purpose of antiracism - the abolition of white supremacy and injustice.

(6) Racism is no respecter of persons, no matter how "liberal" one's background may have been. Whites all over the globe are raised with an almost subconscious and inherent sense of superiority that must be constantly guarded against. White antiracists should labor to subjugate the desire for white control over antiracist organizational forms and allow for non-white leadership and/or join the rank and file positions of non-white antiracist organizations and work for the realizations of the agendas of those organizations.

(7) Antiracist "activism" should be constituted by both study and action: there should be more implementation of the ideas discussed in antiracist 'think-tanks.' This manner of activism should then lead to an articulation of, and demand for, non-white selfdetermination, while simultaneously recognizing the limitations of resolving racism without large-scale transformation in economic, religious, educational, and familial institutions. Failure to do so will result in an unchallenged whiteness that will always threaten to reproduce racism in the antiracist movement. 
Going beyond the socially acceptable limits of "activism” and "protest" is, at this point, a necessary step in the evolution of white antiracism if it seeks fidelity with its core mission. Despite these aforementioned necessary - but by no means absolute-positions, such an undertaking gestures toward the enormity of the task that one necessarily confronts when attempting to comprehend and recuperate the task of a critical, cultural, and reflexive antiracist project for those most in need in our contemporary moment.

\section{Notes}

${ }^{1}$ For instance, see the debate between Mara Loveman (1999). "Comment: Is ‘Race’ Essential?” American Sociological Review 64(6): 892-98 and Eduardo Bonilla-Silva (1999). "Reply: The Essential Social Fact of Race.” American Sociological Review 64(6): 899-906. This dispute was spurred by the publication of Bonilla-Silva's "Rethinking Racism: Towards a Structural Interpretation.” American Sociological Review 62(3) (1997): 465-480, which argued that racialized, hierarchical social systems emerged as a part of the globalization processes of the 1400s-1500s, and that once entrenched, socially existing races arose with distinctive objective interests often pitted against one another. Loveman argued that Bonilla-Silva was reifying race and that the category of race should be abandoned and should rather be seen as an act of "practice" or process that would refocus attention on racial boundary construction, maintenance, and decline. Loveman's point was “it is not axiomatic that membership in a category will correspond directly to experienced group boundaries or social identities” (1999: 892).

${ }^{2}$ Bonilla-Silva (2003) argues that "abstract liberalism” relies on illformed notions of equal opportunity and economic liberalism to explain the racial status quo. The use of the "language of liberalism," exemplified by, "I am all for equal opportunity, that's why I oppose affirmative action," allows one to argue against all measures to eradicate de facto racial inequality, while seeming reasonable and moral. "Naturalization," captured by the tautological notion that the current state of racial inequality is "just the way things are," is a frame that whites utilize to explain phenomena such as segregation as a natural, and thus a non-racial, occurrence. The "cultural racism" frame, illustrated by, "black people are on welfare and have too many babies," explains the status of racial minorities as a product of cultural deficiencies. Finally, the frame of "minimiza- 
tion," reflected in, "It's better now than in the past” or, “There is discrimination, but there are plenty of jobs out there" downplays the significance that race plays in the life chances of non-whites in the United States. Bonilla-Silva contends that whites utilize these frames both independently and collectively to argue against measures to improve the status of blacks, while turning a blind eye to the reality of racial inequality.

${ }^{3}$ This term is used by Karyn McKinney in Being White. 2004. NY: Routledge, and by Melanie E. L. Bush in Breaking the Code of Good Intentions: Everyday Forms of Whiteness. 2004. NY: Rowman and Littlefield Publishers, Inc. The term is used to define those whites in the United States who are not active in racial politics and who may not consider race and racial matters that important of an issue. When they do consider race, they are often prone to explaining both the cause and effect of racialized phenomena to that of non-racial characteristics, patterns, traditions, habits, and ideologies.

${ }^{4}$ Fieldview University's undergraduate student racial demographic makeup is: black (09\%); Asian (11\%); Hispanic (03\%); Native American (0.2\%); non-resident/unclassed (11\%), and white (67\%). Reformed Relations discussion group of which I was a member (excluding myself) is composed of two black males, four white males, one black female, and three white females (ages 19-23, from roughly upper middle-class backgrounds).

${ }^{5}$ The pseudonyms used for these ten members are: Allie (white woman), Jane (white woman), Jasmine (white woman), Kim (white woman), Kris (black man), Lisa (black woman), Michelle (white woman), Natalie (white woman), Mark (white man), and Michael (white man).

${ }^{6}$ Apache. "Kill d'White People" Apache Ain't Shit. 1993, Tommy Boy Music, Time Warner, USA.

${ }^{7}$ After that meeting, I spoke with Allie about what she was specifically referencing. She was referring to the famous reorganization of SNCC (Student Nonviolent Coordinating Committee) in 1966. After the Watts Riots in Los Angeles in 1965, many within SNCC grew skeptical about the tactics of nonviolence, and sought to break their ties with the mainstream civil rights movement and the liberal white organizations that supported it, arguing instead that blacks needed to seize power rather than seek accommodations from the white power structure. The leader of this movement, Stokely Carmichael (later Kwame Toure), replaced John Lewis as head of SNCC in May 1966 and SNCC soon thereafter expelled its white staff and volunteers and denounced the whites who had supported it in the past 
${ }^{8}$ I became a member of the historically African American fraternity, Phi Beta Sigma Fraternity, Inc. in the fall of 1996.

${ }^{9}$ Allie is referencing Beverly Daniel Tatum's (2003) Why Are All The Black Kids Sitting Together In The Cafeteria?. The work explores the mechanisms and tribulations concerning black student attempts at securing a positive racial identity in a majority white educational environment.

${ }^{10}$ Fieldview University's undergraduate student (population approximately 14,000) racial demographic makeup is: black (nine percent; Asian (eleven percent); Hispanic (three percent); Native American (less than one percent); non-resident/unclassed (eleven percent), and white (sixty percent). Out of the eighty-five total members in RR, the racial demographic makeup is: black (five members; six percent); Hispanic (two members; two percent); East Indian (two members; two percent); white (seventy-seven; eighty-nine percent). Thus, RR is more segregated then the general student population by a ratio of 1.48 .

${ }^{11}$ Many antiracist organizations exist at Fieldview. At the time of this research, sixty-seven non-white student organizations were active at Fieldview University, and nine of those sixty-seven advocated an explicitly antiracist agenda.

${ }^{12}$ Following a string a campus racial incidents during the 2004-2005 academic year, the administration called a special board of inquiry into session to formulate a plan of action for resolving racial conflict on campus. RR was the only student group asked to participate in the design and implementation of the plan.

\section{References}

Alcoff, L. 1991-92. "The Problems of Speaking for Others.” Cultural Critique 20: 5-32.

Althusser, L. 1971. Lenin and Philosophy, and Other Essays. London, UK: New Left Books.

Andersen, M. L. 2001. "Restructuring for Whom? Race, Class, Gender, and the Ideology of Invisibility.” Sociological Forum 16(2): 181201.

Anderson, B. 1983 [1991]. Imagined Communities: Reflections on the Origin and Spread of Nationalism. London and NY: Verso.

Barkun, M. 1994. Religion and the Racist Right: The Origins of the Christian Identity Movement. Chapel Hill, NC: University of North Carolina Press. 
Blee, K. M. 2002. Inside Organized Racism: Women in the Hate Movement. Berkeley, CA: University of California Press.

Bobo, L., J. R. Kluegel, and R. A. Smith. 1997. "Laissez Faire Racism: The

Crytallization of a 'Kinder, Gentler' Anti-Black Ideology.” In Racial Attitudes in the 1990s: Continuity and Change, edited by S. A. Tuch and J. K. Martin. Westport, CT: Praeger.

Bobo, L. and J. R. Kluegel. 1993. "Opposition to Race-Targeting: Self Interest, Stratification Ideology, or Racial Attitudes?” American Sociological Review 58(4): 443-64.

Bonnett, A. 2000. Anti-Racism. NY: Routledge.

Bonnett, A. 1997. "Constructions of Whiteness in European and American Anti-Racism.” Pp 173-192 in Debating Cultural Hybridity: MultiCultural Identities and the Politics of Anti-Racism, edited by P. Werbner and T. Modood. London: Zed Books.

Bonnett, A. 1993. Radicalism, Anti-Racism and Representation. NY: Routledge.

Bonilla-Silva, E. 2003. Racism Without Racists. Lanham, MD: Rowman \& Littlefield.

Bonilla-Silva, E. 2001. White Supremacy \& Racism in the Post-Civil Rights Era. Boulder, CO: Lynne Rienner.

Bourdieu, P. 1984. Distinction. Cambridge, MA: Harvard University Press. Brekhus, W. 1998. "Sociology of the Unmarked: Redirecting our Focus." Sociological Theory 16: 34-51.

Bryson, B. 2005. Making Multiculturalism. Stanford, CA: Stanford University Press.

Bryson, B. 1996. “'Anything But Heavy Metal’: Symbolic Exclusion and Musical Dislikes.” American Sociological Review 61: 884-899.

Burlein, A. 2002. Lift High the Cross: Where White Supremacy and the Christian Right Converge. Durham, NC: Duke University Press.

Carvery, V. and A. Bishop. 1994. Unlearning Racism: A Workshop Guide to Unlearning Racism. Halifax: Oxfam/Deveric.

Chennault, R. E. 1998. "Giving Whiteness a Black Eye: An Interview with Michael Eric Dyson.” Pp. 299-328 in White Reign: Deploying Whiteness in America, edited by J. L. Kincheloe, S. R. Steinberg, N. M. Rodriguez and R. E. Chennault. NY: St. Martin's Griffin.

Clark, C. and J. O’Donnell. 1999. Becoming and Unbecoming White: Owning and Disowning a Racial Identity. Westport, CT: Bergin \& Garvey.

Delgado, R. and J. Stefancic (eds.). 1997. Critical White Studies: Looking Behind the Mirror, Philadelphia, PA: Temple University Press. 
Doane, A. W. and E. Bonilla-Silva. 2003. White Out: The Continuing Significance of Racism. NY: Routledge.

Du Bois, W.E.B. 1920. Darkwater: Voices from Within the Veil. Mineola, NY: Dover Publications.

Dyer, R. 1997. White. NY: Routledge.

Dyer, R. Autumn 1988. "White.” Screen 29(4): 44-64.

Ellison, R. 1970. "What America Would Be Like Without Blacks.” Pp. 577584 in The Collected Essays, edited by John Callahan. NY: The Modern Library.

Ezekiel, R. S. 1995. The Racist Mind: Portraits of Neo-Nazis and Klansmen. NY: Viking

Fairclough, N. 2003. Analyzing Discourse: Textual Analysis for Social Research. NY: Routledge.

Fanon, F. 1967. Black Skin, White Masks. NY: Grove Press.

Ferber, A. L. 1998. White Man Falling: Race, Gender and White Supremacy. Lanham, MD: Rowman and Littlefield.

Firebaugh, G. and K. Davis. 1988. "Trends in Antiblack Prejudice, 19721984: Region and Cohort Effects.” American Journal of Sociology 94: 251-72.

Frankenberg, R. 1997. Displacing Whiteness: Essays in Social and Cultural Criticism. Durham, NC: Duke University Press.

Frankenberg, R. 1993. White Women, Race Matters: The Social Construction of Whiteness. Minneapolis, MN: University of Minnesota Press

Gable, G. 1994. "Integrating Case Study and Survey Research Methods: An Example in Information Systems." European Journal of Information Systems 3(2): 112-126.

Gadamer, H. G. 1984. [2002]. “The Hermeneutics of Suspicion.” Pp. 54-65 in Hermeneutics: Questions and Prospects, edited by G. Shapiro and A. Sica. Amherst, MA: University of Massachusetts Press.

Gans, H. 1979. "Symbolic Ethnicity: The Future of Ethnic Groups and Cultures in America," Ethnic and Racial Studies 2: 1-20.

Garfinkel, H. 1967. Studies in Ethnomethodology. Englewood Cliffs, NJ: Prentice Hall.

Ginsberg, E. K. 1996. Passing and the Fictions of Identity. Durham, NC: Duke University Press.

Glasner, B. and A. Strauss. 1967. The Discovery of Grounded Theory: Strategies for Qualitative Research. Hawthorne, NY: Aldine.

Hall, S. 1980. Encoding /Decoding. In Culture Media and Language: Working Papers in Cultural Studies, edited by S. Hall, D. Hobson, A. Lowe and P. Willis. London, UK: Hutchinson. 
Hartigan, Jr. J. 1999. Racial Situations: Class Predicaments of Whiteness in Detroit. Princeton, NJ: Princeton University Press.

Hooks, B. 1992. Black looks: Race and representation. Boston: South End Press.

Hughes, L. 1934. The Ways of White Folks. NY: Knopf.

Hughey, M. 2006. "Specters of Whiteness: The (Mis)Educational Reproduction of 'Anti-racist' Racism.” Pp. 21-43 in Ethnographic and Qualitative Research in Education, edited by P. Brewer and M. Firmin. New Castle, UK: Cambridge Scholars Press.

Hyde C. 1995. The Meanings of Whiteness. Qualitative Sociology 18: 87-95 Jackman, M. R. 1994. The Velvet Glove: Paternalism and conflict in gender, class and race relations. Berkeley and Los Angeles: University of California Press. Jackman, M. R. and M. J. Muha. 1984. "Education and Intergroup Attitudes: Normal Enlightenment, Superficial Democratic Commitment, or Ideological Refinement?” American Sociological Review, 49: 751-769.

Jensen, R. 2005. The Heart of Whiteness: Confronting Race, Racism and White Privilege. San Francisco, CA: City Lights Books.

Jick, T. D. 1983. "Mixing Qualitative and Quantitative Methods: Triangulation in Action.” Pp 135-148 in Qualitative Methodology, edited by J. Van Maanen. Beverley Hills CA: Sage Publications.

Kaplan, B. and D. Duchon. 1988. "Combining Qualitative and Quantitative

Methods in Information Systems Research: A Case Study.” MIS Quarterly 12(4): 571-586.

Katz , J. 2003 [1978]. White Awareness: Handbook for Anti-Racism Training, Norman, OK: University of Oklahoma Press.

Kinder D. and L. Sanders. 1996. Divided by Color: Racial Politics and Democratic Ideals. Chicago: University of Chicago Press.

Kinder, D. R. and L. M. Sanders. 1996. Divided by Color: Racial Politics and Democratic Ideals. Chicago, IL: University of Chicago Press.

Kinder, D. R. and D. O. Sears. 1981. "Prejudice and Politics: Symbolic Racism versus Racial Threats to the Good Life." Journal of Personality and Social Psychology 40: 414-31.

Kivel, P. 1996. Uprooting Racism. Montpelier,VT: New Society Publishers. Knafl, K.A. and B. J. Breitmayer. 1989. "Triangulation in Qualitative Research: Issues of Conceptual Clarity and Purpose.” Pp 226-233 in Qualitative Nursing Research As Contemporary Dialogue, edited by J. M. Morse. Rockville, MD, Aspen.

Langer, E. 2003. A Hundred Little Hitlers: The Death of a Black Man, the Trial of a White Racist, and the Rise of the Neo-Nazi Movement in America. NY: Metropolitan. 
Lee, A. S. 1991. "Integrating Positivist and Interpretive Approaches to Organizational Research.” Organization Science 2: 342-365.

Levitas, D. 2002. The Terrorist Next Door: The Militia Movement and the Radical Right. NY: Thomas Dunne/St. Martin's.

Lipset, S. 1996. American Exceptionalism. NY: Norton.

Lipsitz, G. Sept. 1995. "The Possessive Investment in Whiteness." American Quarterly 47(3): 369-86.

Lofland, J. and L. H. Lofland. 1995. Analyzing Social Settings: A Guide to Qualitative Observation and Analysis. Belmont, CA: Wadsworth. Marty, D. 1999. "White Antiracist Rhetoric as Apologia: Wendell Berry's The Hidden Wound." Pp. 51-68 in Whiteness: The Communication of Social Identity, edited by T. K. Nakayama and J. N. Martin. Thousand Oaks, CA: Sage.

McConahay, J. B. 1986. "Modern Racism, Ambivalence, and the Modern Racism Scale.” Pp. 91-125 in Prejudice, Discrimination and Racism, edited by J. F. Dovidio and S. L. Gaertner. NY: Academic.

Miles, M. B. and A. M. Huberman. 1994. Qualitative Data Analysis. Thousand Oaks, CA: Sage Publications.

Mingers, J. 2001. "Combining IS Research Methods: Towards a Pluralist Methodology.” Information Systems Research 12(3): 240-259.

O’Brien, E. 2001. Whites Confront Racism: Antiracists and Their Paths to Action. Boulder, CO: Rowman and Littlefield.

Orfield, G. and C. Lee. 2006. "Racial Transformation and the Changing Nature of Segregation.” Cambridge, MA: The Civil Rights Project at Harvard.

Orfield, G. and J. T. Yun. June 1999. "Resegregation in American Schools.” Cambridge, MA: The Civil Rights Project at Harvard.

Potak, M. 2005. "The Year in Hate, 2005.” Intelligence Report. Montgomery, AL. Southern Poverty Law Center.

Ragin, C. C. 1987. The Comparative Method: Moving Beyond Qualitative and Quantitative Strategies. Berkeley and London: University of California Press.

Ridgeway, J. 1990. Blood in the Face: The Ku Klux Klan, Aryan Nations, Nazi Skinheads, and the Rise of a New White Culture. NY: Thunder's Mouth.

Roediger, D. 1994. Towards the Abolition of Whiteness. London, UK: Verso.

Schuman, H., C. Steeh, L. Bobo, and M. Krysan. 1997. Racial Attitudes in America: Trends and Interpretations. Cambridge, MA: Harvard University Press. 
Sears, D. O. 1988. “Symbolic racism.” Pp. 53-84 in Eliminating Racism: Profiles in Controversy, edited by P. A. Katz and D. A. Taylor. NY: Plenum Press.

Sears, D. and D. Kinder. 1971. "Racial Tensions and Voting in Los Angeles." Pp. 51-88 in Los Angeles: Viability and Prospects for Metropolitan Leadership, edited by W. Hirsch. NY: Praeger.

Sharpe, T. T. 2000. "The Christian Identity Movement: Ideology of Domestic Terrorism.” Journal of Black Studies 30(4): 604-623.

Sheatsley, P. 1966. "White Attitudes Toward the Negro.” Daedalus 95(1): 217-38.

Sidanius, J., P. Singh, J. Hetts, and C. Federico. 2000. “It’s Not Affirmative Action: It's the Blacks.” Pp. 191-235 in Racialized Politics: The Debate about Racism in America, edited by D. Sears, J. Sidanius, L. Bobo. Chicago, IL: University of Chicago Press.

Smith, D. 1986. "Institutional Ethnography: A Feminist Method.” Resource for Feminist Research 15: 6-13.

Smith, G. 1990. "Political Activist as Ethnographer.” Social Problems 37: $629-48$.

Sniderman, P. and E. Carmines. 1993. Reaching Beyond Race. Cambridge, MA: Harvard University Press.

Srivastava, S. 2005. “'You're Calling Me a Racist?”: The Moral and Emotional Regulation of Anti-Racism and Feminism.” SIGNS: Journal of Women and Culture in Society 31(1): 29-62.

Srivastava, S. 1996. "Song and Dance? The Performance of Antiracist Workshops." Canadian Review of Sociology and Anthropology 33(3): 292-316.

Tatum, B. 1995. Why Are All the Black Kids Sitting Together in the Cafeteria? NY: Basic.

Thompson, B. 2001. A Promise and A Way of Life. Minneapolis, MN: University of Minnesota Press.

Thompson, C., E. Schaefer and H. Brod. 2003. White Men Challenging Racism, 35 Personal Stories. Durham, NC: Duke University Press.

Waters, M. 1990. Ethnic Options: Choosing Identities in America. Berkeley, CA: University of California Press.

Wade, Wyn Craig. 1987. The Fiery Cross: The Ku Klux Klan in America. NY: Simon and Schuster.

Weber, S. 1985. "The Intersection: Marxism and the Philosophy of Language.” Diacritics: A Review of Contemporary Criticism 15(4): 109-118. 
Wilson, W. J. 1869 [1999]. "What Shall We Do With The White People?” Pp. 58-66 in Black on White: Black Writers on What it Means to be White, edited by D. Roediger. NY: Schocken Press.

Winant, H. 2001. The World is a Ghetto: Race and Democracy Since World War II. NY: Perseus Books.

Winant, H. 2004 [1997] "Behind Blue Eyes: Whiteness and Contemporary U.S. Racial Politics.” Pp. 3-16 in Off White: Readings on Race, Power, and Society, edited by M. Fine, L. Weis, L C. Powell, and L Mun Wong. NY: Routledge. 